OLGA BARBURSKA

Centrum Europejskie Uniwersytetu Warszawskiego

DOI : $10.14746 /$ rie.2016.10.21

\title{
Argument sily czy sila argumentów? Unia Europejska w stosunkach międzynarodowych jako soft power
}

Jedną z głównych cech wyróżniających Unię Europejską spośród innych uczestników współczesnych stosunków międzynarodowych jest specyfika prowadzonej przez nią polityki zagranicznej. Badanie tej specyfiki może stanowić przedmiot osobnych, obszernych rozważań, prowadzących zresztą do kontrowersji badawczych, dotyczących kwestii tak podstawowych jak zakres pojęciowy czy nazewnictwo (Barburska, 2016; Zajączkowski, 2014; Zięba, 2011; Grosse, 2009). Nie wchodząc zatem w analizę tego rodzaju zagadnień należy tylko wskazać, że unijna polityka zagraniczna - czy szerzej, funkcjonowanie Unii w świecie - charakteryzuje się m.in. odgrywaniem przez nią unikatowych, właściwych jej ról międzynarodowych.

Problematyka ról międzynarodowych również stanowi odrębne, bardzo rozległe zagadnienie, tak więc tu wystarczy podać jedynie wyjściowe, podstawowe założenie badawcze. I tak, generalnie rzecz biorąc, można określić, że rola międzynarodowa jest spójnym systemem wybranych przez daną jednostkę polityczną (w tym przypad$\mathrm{ku}$ - Unię Europejską) działań i zachowań w ramach swych relacji ze światem zewnętrznym, co odbywa się przy wykorzystaniu posiadanego przez nią potencjału oraz zgodnie z przyjętym przez nią katalogiem zasad i systemem wartości (Antczak, 2012; Milczarek, 2003; Pietraś, 1989).

Odgrywane przez UE role międzynarodowe można dzielić zgodnie z różnymi klasyfikacjami, spośród których dla potrzeb niniejszych rozważań wskazać trzeba dwie podstawowe kategorie. Pierwsza $\mathrm{z}$ nich obejmuje role wiążące się z wykorzystywaniem „twardych" (hard) instrumentów przymusu (w tym siły zbrojnej) oraz role, za pomocą których oddziałuje się na otoczenie zewnętrzne za pomocą ,łagodnych” (soft) środków o charakterze politycznym, dyplomatycznym, ekonomicznym, kulturowym itp. (Parzymies, 2009, s. 24 passim). Pomimo pewnych kontrowersji interpretacyjnych w tym zakresie, nie ulega wątpliwości, że zdecydowana większość ról spełnianych przez Unię wpisuje się w tę drugą kategorię. Oznacza to, że Unia Europejska jako uczestnik stosunków międzynarodowych stanowi swoistą „łagodną potęgą” (soft power).

Przyjmując takie założenie badawcze należy od razu podkreślić, że idea soft power może dobrze służyć jako swoista podstawa koncepcyjna lub punkt wyjścia dla innych, różnorodnych teorii. Wprawdzie takie ujęcie tego zagadnienia nie jest powszechnie stosowane w literaturze przedmiotu, chociażby z tego względu, że teorie te nie zawsze były skorelowane i powiązane ze sobą chronologicznie. Ponadto wywodziły się one z rozmaitych głównych szkół badawczych - w tym przede wszystkim realizmu, liberalizmu i konstruktywizmu - które, jak wiadomo, opierają się na odmiennych założeniach. Niemniej za uznaniem koncepcji soft power za najbardziej ogólną przemawia to, że zdaje się ona posiadać największą, w porównaniu z innymi teoriami, pojemność 
pojęciową. Innymi słowy, może ona stanowić swoisty wspólny mianownik czy też zwornik dla całej gamy różnych podejść badawczych.

Takie ujęcie będzie zatem zastosowane w niniejszych rozważaniach, w ramach których koncepcja „łagodnej potęgi” będzie stanowić podstawowy punkt wyjścia do podjęcia próby określenia specyfiki UE jako unikatowego uczestnika stosunków międzynarodowych - także przy wykorzystaniu teorii pochodnych, w tym przede wszystkim koncepcji civilian power. Przed przejściem do ich zaprezentowania konieczna jest jednak analiza koncepcji wyjściowej, czyli zastosowania teorii soft power do badania fenomenu Unii Europejskiej.

\section{Soft power a Unia Europejska}

Koncepcje hard power i soft power zaproponował na przełomie lat 80. i 90. Joseph S. Nye. Odniósł je wprawdzie do polityki Stanów Zjednoczonych, ale jego idea znalazła szerokie zastosowanie w politologii i nauce o stosunkach międzynarodowych, a ostatecznie także w europeistyce (Nye, 2007; Nye 2011). W sensie pojęciowym pierwsza z tych koncepcji oznacza dysponowanie przez daną jednostkę polityczną możliwościami wywierania przymusu (zresztą nie tylko militarnego, ale także ekonomicznego czy politycznego) na innych uczestników stosunków międzynarodowych po to, aby postępowali zgodnie z wolą tej jednostki.

Natomiast soft power oznacza, zdaniem Nye'a, dysponowanie przez daną jednostkę polityczną możliwościami oddziaływania na otoczenie zewnętrzne za pomocą instrumentów politycznych, prawnych i gospodarczych, ale przede wszystkim dzięki ,sile przyciagania", czyli wykorzystywaniu swojej własnej atrakcyjności cywilizacyjnej. Do najważniejszych zasobów umożliwiających odgrywanie takiej „przyciagającej” roli można zaliczyć dysponowanie budzącym zainteresowanie potencjałem kulturowym, systemem wartości powszechnie akceptowanych w świecie oraz skuteczną polityką zagraniczną, opartą na tych właśnie wartościach (Nye, 2007, s. 6). Innymi słowy, „oddziaływanie mocarstwa uważanego za soft power wynika nie tyle z jego siły przekonywania, co atrakcyjności, jaką potrafi demonstrować na arenie międzynarodowej jego społeczeństwo i system polityczny" (Parzymies, 2009, s. 31)

Stosowanie takich „miękkich" zasobów pozwala zatem osiagać własne cele polityczne, gospodarcze i każde inne oraz kształtować zgodnie z nimi otoczenie zewnętrzne i preferencje innych uczestników stosunków międzynarodowych nie poprzez stosowanie przymusu, ale dzięki własnej szeroko rozumianej atrakcyjności. Przejawiać się to może w bardzo różny sposób, m.in. w formie wywierania wpływów kulturowych, promowania własnych wartości polityczno-ideologicznych, sprawowania przywództwa w sferze wiedzy i komunikacji, rozpowszechniania zasad prawa międzynarodowego, stosowania wielostronnej dyplomacji, rozwijania współpracy gospodarczej itp.

Kategoria soft power znalazła szerokie zastosowanie w badaniach nad fenomenem Unii Europejskiej jako uczestnika stosunków międzynarodowych, gdyż dobrze uwzględnia specyficzne cechy jej polityki zagranicznej. Chodzi tu przede wszystkim o fakt, który niejako z założenia i de facto czyni z UE swoistą „łagodną potęge”, a mianowicie o to, że polityka ta opiera się na katalogu tzw. wartości europejskich. 
Ani ta nazwa, ani ten katalog nie zostały nigdzie w całości oficjalnie ogłoszone, ale wydaje się, że ich funkcjonowanie jako odrębnej kategorii jest zarówno obiektywnie istniejącym faktem, jak też badawczą potrzebą. Nie wnikając w szczegółowe rozważania definicyjne na ich temat, wystarczy wskazać, że obejmują one normy zarówno o charakterze polityczno-ideologicznym, jak też odnoszące się do specyficznego, europejskiego modelu rozwoju społeczno-gospodarczego.

Katalog „wartości europejskich” najpełniej został przedstawiony w kluczowym akcie prawa wspólnotowego, jakim jest traktat o Unii Europejskiej (TUE) w jego formie z Lizbony. W jego preambule i art. 2 znajdują się zapisy powołujące się na najważniejsze ,powszechne wartości”, do których zalicza się wolność, demokrację, poszanowanie praw człowieka i podstawowych wolności (w tym praw osób należących do mniejszości), równość, państwo prawne. Te wartości mają funkcjonować w społeczeństwie opartym na pluralizmie, niedyskryminacji, tolerancji, sprawiedliwości, solidarności oraz równości kobiet i mężczyzn. W art. 3, ust. 3 zasady te rozpisane są w sposób jeszcze bardziej szczegółowy, odnosząc się m.in. do zwalczania wykluczenia społecznego, wspierania zrównoważonego rozwoju gospodarczego, ochrony środowiska naturalnego czy poszanowania europejskiego dziedzictwa kulturowego.

Ze względu na swoje ogólne znaczenie wszystkie powyższe normy odnoszą się pośrednio lub bezpośrednio do sfery polityki zagranicznej UE, ale sfera ma $\mathrm{w}$ TUE także swój osobny katalog normatywny. We wspomnianym art. 3, ust. 5 zapisano, że „W stosunkach zewnętrznych Unia umacnia i propaguje swoje wartości”, do których zalicza się (oprócz wymienionej wyżej ochrony praw człowieka) przyczynianie się do pokoju, bezpieczeństwa, trwałego rozwoju Ziemi, solidarności i wzajemnego szacunku między narodami, swobodnego i uczciwego handlu, wyeliminowania ubóstwa oraz ścisłego przestrzegania i rozwoju prawa międzynarodowego, w tym zwłaszcza zasad Karty Narodów Zjednoczonych (Traktat z Lizbony, 2010, s. 15-20).

Bardziej szczegółowo normy te zostały przedstawione w art. 21, w którym zapisano m.in., że w ramach „rozwijania stosunków i budowania partnerstwa” z państwami trzecimi oraz organizacjami międzynarodowymi Unia sprzyja ,wielostronnym rozwiązaniom wspólnych problemów". Ponadto UE jest gotowa nieść pomoc narodom, krajom i regionom na wypadek klęsk żywiołowych czy katastrof spowodowanych przez człowieka czy też wspiera system międzynarodowy oparty na silniejszej współpracy wielostronnej i na „dobrych rządach” (good governance) w skali ogólnoświatowej. Bardzo ważne znaczenie mają zapisy dotyczace utrzymywania pokoju, zapobiegania konfliktom i umacnianiu bezpieczeństwa międzynarodowego zgodnie z zasadami i celami Karty NZ oraz innych kluczowych aktów prawnych, takich jak Akt Końcowy z Helsinek czy Karta Paryska (Traktat z Lizbony, 2010, s. 31-32). Waga wszystkich tych powyższych postanowień wynika z przyjęcia domyślnie - chociaż nie ze sformułowania wprost - fundamentalnej zasady, że Unia Europejska w relacjach ze światem zewnętrznym ogranicza czy po prostu powstrzymuje się od użycia siły militarnej, preferując pokojowe metody rozwiązywania problemów międzynarodowych.

Zasada ta, a także wszystkie wskazane wyżej wartości zostały uznane za podstawy prawne i ideologiczno-polityczne całości procesów integracji europejskiej (Barburska, 2013, s. 75 passim). Zostały one nie tylko zapisane w traktatach UE, ale też potwierdzone w licznych dokumentach unijnych, w których stwierdza się wprost, że 
„ochrona praw podstawowych jest zasadą założycielską Unii” (cyt. za Manners, 2000, s. 241). Należy z naciskiem podkreślić, że stanowi to cechę zdecydowanie odróżniającą Unię Europejską od innych uczestników stosunków międzynarodowych i tym samym w znacznym stopniu decydująca o jej unikatowym charakterze (Smith K., 2000, s. 185 passim; von Bogdandy, s. 1307-1308).

Samo istnienie, ale nade wszystko stosowanie „wartości europejskich” ma w kontekście niniejszych rozważań bardzo istotne znaczenie. Skoro wartości te stanowią bazę normatywną dla całej aktywności międzynarodowej Unii Europejskiej, oznacza to, że są one także podstawą dla jej rozmaitych ról międzynarodowych, w tym zwłaszcza - dla odgrywania roli soft power. Odgrywanie takiej roli stanowi zatem podstawowy element czyniący z UE uczestnika stosunków międzynarodowych będących „łagodną potegga”. Pod tym względem Unia prezentuje się jako jednostka polityczna tak bardzo unikatowa we współczesnym świecie, że wręcz można mówić, jak określiła to Helene Sjursen, o swoistej „europeizacji” samego pojęcia soft power (Sjursen, 2006, s. 235). Atrakcyjność UE w tym zakresie przejawia się zwłaszcza w aspekcie kulturowym (powszechna znajomość w świecie europejskich języków oraz szeroko rozumianego dorobku kulturowo-cywilizacyjnego), a także aksjologicznym, dzięki ogólnemu uznaniu „wartości europejskich” za wzorcowe ${ }^{1}$.

W zakresie tego typu oddziaływania - jak określił to już wiele lat temu Johan Galtung - „Wspólnota Europejska jest szczególnie silna” (Galtung, 1973, s. 36); być może nawet silniejsza niż jej największy konkurent w tej dziedzinie, Stany Zjednoczone. Jako dowód można przytoczyć opinie na ten temat wygłaszane przez amerykańskich badaczy, jak np. Roberta Kagana. Autor ten jest znany ze swych obrazowych stwierdzeń, że „Amerykanie są z Marsa, a Europejczycy z Wenus”, które rozwijał dokonując porównań pomiędzy politykami zagranicznymi USA i UE. Jak słusznie zauważał, „w konfrontacji z przeciwnikiem Amerykanie wolą przymus od perswazji”, natomiast Europejczycy „na ogół wybierają pokojowe rozwiązania, od przymusu wolą negocjacje, dyplomację i perswazję", co może przynosić większe i trwalsze efekty, niż stosowanie siły. Innymi słowy, „Europejczycy widzą swój interes w budowaniu świata, w którym potęga militarna ma mniejsze znaczenie niż potęga gospodarcza; w którym prawo i instytucje międzynarodowe znaczą więcej niż siła pojedynczych krajów" (Kagan, 2003, s. 3 passim; Parzymies, 2009, s. 30). Również niektórzy czołowi politycy amerykańscy pozytywnie oceniają normatywny aspekt międzynarodowej aktywności UE - tak np. zdaniem Donalda Rumsfelda „siła militarna Europy, jej hard power może się nie liczyć, jednak jej soft power [...] jest naprawdę ogromna" (cyt. za Piskorska, 2014, s. 25-26).

Jednym z wielu przejawów przyjmowania przez Unię Europejską ,,wartości europejskich" jako podstawy dla jej polityki zagranicznej było przyjęcie określonych postanowień w ważnym dokumencie unijnym, jakim była Europejska Strategia Bezpieczeństwa (ESB), uchwalona w 2003 r. i zaktualizowana pięć lat później. Wśród trzech podstawowych celów Strategii, oprócz przeciwdziałania najważniejszym zagrożeniom stojącym przed UE, dokument ten przewiduje wnoszenie wkładu w stabilizację i rozwój regionów sąsiednich, jak też tworzenie porządku międzynarodowego opartego na „efektywnym multilateralizmie". Wprawdzie dokument ten przewiduje stosowanie także innych środ-

${ }^{1}$ Jednym z wielu aspektów tej atrakcyjności jest fakt, że połowa z dziesięciu najczęściej używanych na świecie języków to języki europejskie (Parzymies, 2009, s. 31-32). 
ków typu hard power, to niemniej proponowana przez Federicę Mogherini, pełniącą obecnie funkcję Wysokiego Przedstawiciela UE do Spraw Zagranicznych i Polityki Bezpieczeństwa, nowelizacja Strategii zakłada nadal opieranie się w zasadniczej mierze na zasadach soft power. Jak stwierdzono wprost w projekcie zmian przygotowanym w połowie 2016 r.: „Unia Europejska jest dumna ze swojej «miękkiej siły» i wciąż będziemy na niej polegać”, gdyż ,jesteśmy w tym najlepsi” (Nowa, 2016).

Wśród wszystkich norm wchodzących w skład katalogu „wartości europejskich”, a odnoszących się do sfery relacji UE ze światem zewnętrznym, najważniejsze znaczenie mają jednak dwie podstawowe: ograniczenie się czy też powstrzymanie się od użycia siły militarnej oraz promowanie szeroko rozumianych wartości demokratycznych (Milczarek, 2005, s. 14 passim). Na obu tych normach opiera się wspomniana już koncepcja bezpośrednio nawiązująca do teorii traktującej Unię Europejską jako soft power - chodzi o koncepcję civilian power. Jej założenia wydają się bardzo dobrze wpisywać w myśl przewodnią idei UE jako ,łagodnej potęgi”, z tego też względu zasługuje ona na dokładniejszą prezentację.

\section{Koncepcja Unii Europejskiej jako civilian power}

Teoria traktująca Unię Europejską jako „civilian power” (nazywaną tu „,mocarstwem niewojskowym") ${ }^{2}$ wywodzi się ze szkoły neoliberalizmu. Zdaniem zwolenników tego podejścia polityka zagraniczna ,kształtuje się pod wpływem przetargów pomiędzy państwami, w których prym wiodą wewnętrzne grupy interesów" (Czaputowicz, 2013, s. 16), a stosunki międzynarodowe opierają się na zasadach współpracy (zwłaszcza gospodarczej), multilateralizmu i stosowania instrumentów pokojowych (Skolimowska, 2015, s. 29). W dużym skrócie istotę koncepcji ,civilian power” można określić następująco: „mocarstwo niewojskowe jest bytem (entity), który oddziałuje na system międzynarodowy, używając głównie środków ekonomicznych, finansowych i politycznych, a nie potęgi militarnej" (Stavridis, 2001, s. 3-4).

Oznacza to, że, z jednej strony, tego typu mocarstwo powstrzymuje się od użycia w swej polityce zagranicznej siły zbrojnej ${ }^{3}$ na rzecz zastosowania środków pokojowych i w konsekwencji - stosuje instrumenty polityczne, dyplomatyczne, ekonomiczne, kulturowe itp., wykorzystywane chętnie w ramach prawa międzynarodowego i organizacji międzynarodowych. Z drugiej strony, drugim podstawowym kryterium wyodrębniającym civilian power powinien być - jak podkreślają niektórzy autorzy - nie tyle sam fakt nieposiadania i nieużywania siły zbrojnej, ile oparcie polityki zagranicznej na określonym katalogu zasad i norm, odpowiadającym de facto katalogowi ,wartości europejskich” (Smith, 2005, s. 22 passim).

${ }^{2}$ Ze względu na fakt, że w polskiej literaturze przedmiotu nie ma ustalonego określenia dla tej koncepcji, funkcjonują jej różne nazwy, spośród których najbardziej odpowiednią wydaje się „mocarstwo niewojskowe". Proponowana jest ona m.in. przez Dariusza Milczarka, dla którego nazwa ta „wydaje się zgrabniejsza od (nieprecyzyjnej pod względem znaczeniowym, gdyż kojarzącej się z kwestiami cywilnoprawnymi) kalki językowej «mocarstwo cywilne» lub też szorstko brzmiącego terminu «mocarstwo niemilitarne»" (Milczarek, 2003, s. 183).

${ }^{3}$ Jak zostanie to wskazane w dalszych rozważaniach, takie powstrzymanie się od użycia siły nie musi - czy nawet nie powinno - być całkowite i bezwarunkowe. 
Do analizy tej szerokiej pod względem pojęciowym koncepcji stosuje się różne podejścia. Zdaniem niektórych badaczy, do zasadniczych cech konstytuujących „mocarstwo niewojskowe" należy traktowanie potencjału ekonomicznego jako podstawowego czynnika zapewniającego realizację celów narodowych, prymat współpracy politycznej i dyplomatycznej w rozwiązywaniu problemów międzynarodowych oraz dążenie do wykorzystywania instytucji i regulacji prawa międzynarodowego do osiągania postępu w skali ogólnoświatowej (Manners, 2002, s. 236-237; Maull, 1990, s. 92-93). Na ten ostatni element wskazują także politycy unijni odwołujący się do idei mocarstwa niewojskowego - jak określił to ówczesny przewodniczący Komisji Europejskiej, Romano Prodi: „Musimy dążyć do stania się globalnym civilian power służącym zrównoważonemu rozwojowi w skali globalnej” (cyt. za Manners, 2002, s. 236).

Autorem koncepcji „mocarstwa niewojskowego" był w latach 70. François Duchêne (Duchêne, 1972; Duchêne, 1973). Jak podkreślał on, Wspólnoty Europejskie odgrywały specjalną rolę w ustanowieniu długotrwałego okresu pokoju w Europie Zachodniej i tym samym mogły służyć jako swoisty model dla innych regionów świata. Ta specyfika polegała właśnie na niestosowaniu w relacjach ze światem zewnętrznym siły militarnej, której malejącą skuteczność pokazywały wówczas takie zjawiska, jak m.in. klęska USA w Wietnamie czy niemożność zapobieżenia przez Zachód kryzysom energetycznym w 1973 i 1979 r. W tej sytuacji teoria civilian power mogła się prezentować jako wiarygodna propozycja przyznania Wspólnotom Europejskim większej, należnej im roli w stosunkach międzynarodowych, uwzględniająca jednocześnie ich specyfikę jako unikatowego, pokojowego uczestnika stosunków międzynarodowych. Zdaniem Duchêne'a, w ten sposób Europa mogłaby „,przezwyciężyć odwieczny ciąg wojen oraz różnych form przemocy" (Duchêne, 1972, s. 43).

W warstwie opisowo-analitycznej jego koncepcja zakładała, że Wspólnoty Europejskie nie są po prostu w stanie dysponować liczącymi się możliwościami militarnymi. Wynikało to przede wszystkim ze stosunkowo niewielkiego potencjału wojskowego ich państw członkowskich, w tym zwłaszcza w odniesieniu do sił nuklearnych, które w okresie ,zimnej wojny” najbardziej liczyły się w skali globalnej. Na dodatek francuski i brytyjski potencjał w tym zakresie w żadnej mierze nie podlegał władzom wspólnotowym, co uwypuklało kolejny problem - braku realnych perspektyw stworzenia przez kraje WE wspólnego, efektywnego systemu podejmowania decyzji w sprawach polityki zagranicznej i bezpieczeństwa. Skoro jednocześnie Wspólnoty były jednak już wielką potęgą ekonomiczna, to wszystko to oznaczało, że „stanowiły mocarstwo niewojskowe z braku innych możliwości (by default)" (Stavridis, 2001, s. 7).

Natomiast $\mathrm{w}$ warstwie normatywnej teoria ta kładła nacisk na konieczność przestrzegania i szerzenia „wartości europejskich”, gdyż WE powinny „stanowić siłę zdolną rozprzestrzeniać w wymiarze międzynarodowym standardy pokojowe i demokratyczne”, czyli dysponować „potęgą idei” (idée force) (Duchêne, 1973, s. 2 i 19). Podkreślało to ideowy (ideational) charakter struktur integracji europejskiej, tym bardziej, że Duchêne za punkt wyjścia dla swej teorii brał szczytne zasady sformułowane w słynnej deklaracji Schumana z 1950 r. Co więcej, zdaniem niektórych badaczy, jak np. Hannsa Maulla, promowanie i stosowanie tego rodzaju zasad stanowiło - jak już wspomniano wyżej - nawet ważniejsze kryterium bycia civilian power, niż samo 
nieposiadanie czy niestosowanie siły militarnej (Maull, 2000, s. 48 passim; Bendiek, Kramer, 2010, s. 464-465).

Następujący od przełomu lat 70. i 80. nawrót „zimnej wojny” w stosunkach Wschód-Zachód w istotnym stopniu pogorszył atmosferę międzynarodową i tym samym „właściwie zlikwidował dyskusję na temat Europy jako (skutecznego) mocarstwa niewojskowego" (Gerrits, 2009, s. 3). Koncepcja ta rzeczywiście spotykała się z krytyką, zwłaszcza ze strony reprezentantów szkoły realizmu politycznego. Zarzucali oni tej teorii brak spójności metodologicznej, niedocenianie znaczenia siły militarnej w stosunkach międzynarodowych (co było widoczne zwłaszcza w ówczesnych warunkach) czy wreszcie nadmierny idealizm polityczny dotyczący „wartości europejskich".

Jednym z czołowych krytyków w ramach tego nurtu był Hedley Bull, który zarzucał, że teoria mocarstwa niewojskowego" stanowi „sprzeczność samą w sobie" (contradiction in terms), gdyż zawiera elementy wykluczające się wzajemnie: pojęcie mocarstwowości i brak pełnego instrumentarium w polityce zagranicznej. Uważał także, że koncepcja ta błędnie nadaje nadmierną użyteczność samym tylko instrumentom politycznym i ekonomicznym, jak też jest pod względem politycznym przejawem „pobożnych życzeń” (wishful thinking). Zdaniem Bulla, Wspólnoty Europejskie powinny dysponować własnym potencjałem militarnym i aby to osiagnać proponował podjęcie konkretnych działań. Miały one obejmować stworzenie własnych wspólnotowych sił nuklearnych, wzmocnienie potencjału europejskich sił konwencjonalnych, większe zaangażowanie w politykę obronną WE czołowych mocarstw: Niemiec, Francji i Wielkiej Brytanii oraz ustanowienie przez Wspólnoty Europejskie „ostrożnego współistnienia” (careful co-existence) zarówno ze Związkiem Radzieckim, jak i Stanami Zjednoczonymi (Bull, 1982, s. 149 passim). Jednym słowem, ,proponowane przez Bulla rozwiązania, zupełnie nierealne w okresie «zimnej wojny» z lat 80., miały zamienić WE w europejskie mocarstwo militarne" (Manners, 2002, s. 237).

Z kolei zwolennicy teorii civilian power podkreślali, że praktyka polityczna wykazała przecież, że pomimo nieposiadania przez Wspólnoty Europejskie efektywnych instrumentów militarnych swej polityki zagranicznej, mogły one w wielu przypadkach relatywnie skutecznie oddziaływać na sytuację w świecie narzędziami ekonomicznymi czy dyplomatycznymi. Co więcej, to właśnie dzięki temu WE zdołały zająć tak wysoką pozycję i odgrywać tak znaczącą rolę, niemającą - jak wskazywał zwłaszcza Christopher Hill - odpowiedników czy precedensów w historii stosunków międzynarodowych (Hill, 1990).

Rezultaty wschodnioeuropejskiej „Jesieni Ludów” z przełomu lat 80. i 90. zmieniające układ sił w Europie oraz na świecie, a także samo powstanie Unii Europejskiej w 1992 r. nadały nowe impulsy debatom wokół omawianej teorii. Z jednej strony, tworzyły się warunki sprzyjające pojmowaniu nowopowstałej Unii jako właśnie ,mocarstwa niewojskowego”, ale z drugiej - „Traktat UE sygnalizował gotowość państw członkowskich Unii do stania się czymś więcej niż civilian power" (Whitman, 1998, s. 144). Jednym z tego przejawów było m.in. utworzenie unijnej Wspólnej Polityki Zagranicznej i Bezpieczeństwa. W dyskusjach na temat tej koncepcji wyodrębniły się wówczas poglądy za i przeciw, które do tej pory wpływają na jej użyteczność w badaniach naukowych i w praktyce politycznej. 
Zwolennicy teorii „mocarstwa niewojskowego” (zwłaszcza ci opowiadający się za jej ortodoksyjną interpretacją) opowiadali się zdecydowanie przeciwko rozwojowi militarnego wymiaru Unii Europejskiej i tym samym za wyrzeczeniem się przez nią dążeń do dysponowania własnym, autonomicznym potencjałem w tej dziedzinie. Uzasadnienie tego typu poglądów wyglądało podobnie jak przytaczane wyżej argumenty z lat 80 ., przy czym - obok uznawania niemilitarnego charakteru europejskich procesów integracyjnych za ich immanentną i pożądaną cechę (Zielonka, 1998; Smith, 2000, s. 11-28) - często wskazywano także obiektywne ograniczenia w wykorzystaniu siły militarnej do realizacji celów polityki zagranicznej (Smith, 1997, s. 17; Hill, 1990, s. 54).

Z kolei spośród poglądów przeciwnych koncepcji civilian power należy wymienić m.in. zarzut, że koncepcja ta służy do usprawiedliwiania czy racjonalizacji swoistej impotencji militarnej Unii Europejskiej. Stanowić to może rodzaj ,intelektualnego alibi" do niepodejmowania w ogóle efektywnych działań na arenie międzynarodowej, $\mathrm{w}$ tym nawet tych z użyciem instrumentów politycznych czy ekonomicznych. Tacy autorzy jak Nicole Gnesotto i Stanisław Parzymies zwracają przy tym uwagę, że najpierw Wspólnoty Europejskie, a następnie Unia Europejska przez długi czas korzystały z tego, że Stany Zjednoczone brały na siebie odpowiedzialność za zapewnienie bezpieczeństwa Europie Zachodniej. W obiektywny sposób pomagało to w utrzymaniu przez WE/UE statusu civilian power, ale może się to zmienić w sytuacji, gdyby USA stopniowo rezygnowały z udzielania tego typu gwarancji, jednocześnie pragnąc przejęcia przez europejskich sojuszników większej odpowiedzialności za bezpieczeństwo własne i globalne. Co więcej, utrzymaniu przez UE statusu „mocarstwa niewojskowego" może przeszkadzać pojawianie się nowych wyzwań globalnych, których skuteczne rozwiązanie może (lub musi) być związane z użyciem siły militarnej (Gnesotto, 2012, s. 162-165; Parzymies, 2009, s. 29).

Zwolennicy i przeciwnicy zgadzali się natomiast w jednym, że przejście UE od stadium "mocarstwa niewojskowego" do mocarstwa rzeczywiście dysponującego efektywną potęgą militarną wymagałoby bardzo ważnych zmian w funkcjonowaniu i przede wszystkim w zarządzaniu unijną polityką zewnętrzną. Konieczne byłoby mianowicie przejście od współpracy międzyrządowej do efektywnych struktur federacyjnych, zwłaszcza w zakresie zarządzania polityką zagraniczną i obronną. Jak określiła to Gnesotto, wymagałoby to pojawienia się bardzo silnego "szoku federacyjnego" (choc federateur), który mógłby doprowadzić do powstania europejskiego państwa federacyjnego dysponującego własną armią (Gnesotto, 2012, s. 163-165).

Taka wizja od początków funkcjonowania koncepcji civilian power wywoływała jednak istotne różnice zdań, wynikające z odmiennych poglądów polityczno-ideowych dotyczących przyszłości oraz finalité politique ogólnych procesów integracyjnych w Europie. Sam Duchêne, chociaż przyznawał, że Wspólnoty Europejskie stały się civilian power właśnie dzięki przekazaniu części uprawnień suwerennych państw na szczebel ponadnarodowy, był przeciwnikiem rozwiązań federalistycznych (Duchêne, 1972, s. 37). Z kolei Galtung twierdził, że WE stanowią ,supermocarstwo w trakcie stawania się", co zakładało konieczność odgrywania prędzej czy później przez zjednoczoną Europę roli potęgi militarnej (Galtung, 1973).

Wyważonej oceny koncepcji civilian power dokonał Stelios Stavridis. Jego zdaniem, w sposób paradoksalny nie ma w zasadzie sprzeczności pomiędzy koncepcją 
Unii Europejskiej jako „mocarstwa niewojskowego” a tendencjami do nadawania jej większego wymiaru militarnego. Należy bowiem brać pod uwagę także normatywny charakter tej teorii dotyczący rozprzestrzeniania „wartości europejskich”. Powoduje to, że „promowanie w świecie zasad demokratycznych może czasami wymagać użycia środków militarnych" (Stavridis, 2001, s. 9-10). Co więcej, może się to okazywać nawet niezbędne dla zapewnienia ogólnej skuteczności działań UE na arenie międzynarodowej, gdyż bycie „mocarstwem niewojskowym” wcale nie opiera się na zasadach naiwnego pacyfizmu. Dopiero bowiem dysponowanie pełnym instrumentarium, w tym narzędziami militarnymi (które by tylko istniały, a nawet nie musiałyby być stosowane), bardzo wzmacniałoby wiarygodność i efektywność unijnej polityki zagranicznej ${ }^{4}$.

W podobny sposób podchodzi do tej kwestii wielu innych badaczy, jak np. Juliet Lodge i Robert Cooper, którzy wskazywali, że „mocarstwo niewojskowe” może wprawdzie dążyć do ograniczenia, ale niekoniecznie do całkowitej eliminacji użycia siły militarnej (Lodge, 1993; Cooper, 2004). Tego typu pragmatyczne podejście do tej koncepcji opowiada się za „odpowiednią kombinacją miękkiej i twardej siły” w ramach unijnej polityki zewnętrznej, gdyż dzięki temu Unia Europejska „orientuje się na zapewnienie bezpieczeństwa jednostek (human security) i jest gotowa do realizowania humanitarnej zasady «odpowiedzialności za ochronę» (resposibility to protect)" (Malinowski, 2012, s. 211). W tym celu prowadzono zresztą konkretne działania, m.in. $\mathrm{w}$ formie podejmowania przez UE misji cywilnych i operacji militarnych służących utrzymywaniu pokoju lub powstrzymywaniu konfliktów zbrojnych w różnych regionach świata ${ }^{5}$.

Ogólnie rzecz biorąc, wydaje się, że mimo upływu wielu lat od momentu jej sformułowania koncepcja „mocarstwa niewojskowego” może nadal służyć jako użyteczna teoria wyjaśniająca funkcjonowanie Unii Europejskiej we współczesnym świecie. Jak określiła to Karen Smith, „debata na temat civilian power dotyczy fundamentalnych wyborów odnoszących się do międzynarodowej tożsamości UE" (Smith, 2000, s. 27). Fakt, że od kilkunastu lat ulega rozszerzeniu militarny wymiar integracji europejskiej można bowiem interpretować jako uzasadniony przejaw realnego dopełniania się tej koncepcji. Oznacza to, jak określił z kolei Stavridis, przejście Unii Europejskiej od odgrywania roli „mocarstwa niewojskowego" „z braku innych możliwości (by default)" do roli civilian power ,Z wyboru (by conviction)" (Stavridis, 2001, s. 20). Świadczą o tym m.in. zapisy Europejskiej Strategii Bezpieczeństwa, przewidującej użycie również „twardych” środków w ramach unijnej Wspólnej Polityki Bezpieczeństwa i Obrony.

Tego rodzaju ewolucja nie zmienia jednak faktu, że co do zasady koncepcja UE jako „mocarstwa niewojskowego” należy do najważniejszych teorii mieszczących się w głównym nurcie teorii traktujących Unię Europejską jako soft power. Podkreśla ona wagę wskazanych wcześniej dwóch najistotniejszych elementów katalogu „wartości

${ }^{4}$ Jako przykład Stavridis podaje występowanie w każdym państwie sił policyjnych, które przecież nie muszą cały czas uciekać się do używania przemocy, aby zapewnić praworządność w kraju (Stavridis, 2001, s. 13).

${ }^{5}$ UE do tej pory zrealizowała w Europie, Afryce i Azji w sumie 17 tego rodzaju misji, głównie cywilnych, a obecnie w trakcie realizacji jest ich 19 (European Union, 2016). 
europejskich", tzn. powstrzymywanie się od stosowania siły zbrojnej oraz promocję wartości demokratycznych. Jak wspomniano we wstępie, funkcjonuje jednak szereg innych koncepcji, także mieszczących się w szeroko pojmowanym nurcie „łagodnej potęgi”. Kładą one, generalnie rzecz biorąc, większy nacisk tylko na jeden z wymienionych wyżej elementów, czyli rozpowszechnianie określonych norm i wartości. Z tego względu w ramach niniejszych rozważań wystarczy omówić je w sposób skrótowy, uznając je raczej za uzupełnienie czy też pochodną teorii soft power.

\section{Koncepcje pochodne wobec teorii soft power}

Wśród innych koncepcji opierających się w mniejszym lub większym stopniu na założeniach soft power można wymienić przede wszystkim teorię wywodzącą się z nurtu konstruktywizmu, która traktuje UE jako „mocarstwo normatywne” (normative power). Uważany za głównego twórcę tej koncepcji, Ian Manners, twierdził, że wszelkie materialne atrybuty potęgi Unii Europejskiej jako aktora globalnego (tj. jej potencjał gospodarczy czy militarny) mają „,drugorzędne znaczenie w porównaniu z jej zdolnościami do kształtowania ideowej (ideational) struktury stosunków międzynarodowej" (Manners, 1999, s. 44; Manners, 2009). Zdolności UE w tym zakresie opierają się „,na znaczeniu idei, norm i wartości leżących u podstaw projektu integracji europejskiej”, a „normatywna siła Unii Europejskiej w relacjach międzynarodowych polega zatem na zdolności do rozprzestrzeniania europejskich norm politycznych, prawnych, idei, dyskursów, wzorców integracji oraz kształtowania za ich pomocą otoczenia międzynarodowego" (Skolimowska, 2015a, s. 12).

Przyjęcie tej koncepcji stanowiło próbę przezwyciężenia dychotomii w spojrzeniu na rolę międzynarodową Unii Europejskiej z punktu widzenia tego, czy jest ona - lub nie jest - albo tylko mocarstwem niewojskowym, albo pełnowymiarową potęga, w tym militarną (Forsberg, 2011; Hyde-Price, 2008; Laïdi, 2008; Sjursen, 2006). Uwzględnienie dodatkowego czynnika ,potegi normatywnej” byłoby, zdaniem Mannersa, doskonałym uzupełnieniem tego typu analiz. Stanowiłoby zarazem odejście, jak on to określił, od „niezdrowego koncentrowania się na badaniu tego, do jakiego stopnia UE przypomina państwo" oraz empirycznej analizy jej instytucji i polityk (Manners, 2002, s. 239). Jednym z zasadniczych elementów tej koncepcji jest bowiem postulat odejścia od widzenia stosunków międzynarodowych w ujęciu państwocentrycznym, opartym na zasadach porządku westfalskiego, czyli innymi słowy - zgodnego z podejściem konstruktywistycznym odejścia od realizmu czy neorealizmu na rzecz normatywizmu. W zamian proponuje się spojrzenie uznające zdolności Unii Europejskiej do dokonywania transformacji stosunków międzynarodowych w kierunku oparcia ich na normach zbliżonych czy wręcz pokrywających się z katalogiem „wartości europejskich”.

Swoistym rozwinięciem czy też uzupełnieniem koncepcji UE jako „mocarstwa normatywnego" są inne, bardziej współczesne teorie, takie jak transformative power. Opracowana przez Marka Leonarda w 2005 r. teoria ta zajęła się badaniem wpływu, jaki Unia wywierała najpierw na państwa postkomunistyczne z Europy Środkowej i Wschodniej aspirujące do członkostwa w UE, a obecnie na innych kandydatów $\mathrm{z}$ tego regionu oraz obszaru Bałkanów. Wpływ ten miał wielkie znaczenie, gdyż dzięki 
wszechstronnemu wsparciu unijnemu doszło w tych państwach do daleko idącej transformacji ustrojowej. Stanowiło to powód do formułowania przez Leonarda daleko idących, ambitnie ujmowanych diagnoz. Jego zdaniem, zastosowanie w tym przypadku przez UE jej „siły transformacyjnej” stanowiło najważniejszą cechę charakteryzującą ewolucję stosunków międzynarodowych od czasów powstania państw narodowych. Działająca długofalowo siła ta ma doprowadzić, na zasadzie swoistego efektu domina, do daleko idących przemian zarówno wśród bezpośrednich sąsiadów Unii, jak też w całej Europie, ale również spowodować generalne zmiany w postrzeganiu koncepcji siły w XXI wieku (Leonard, 2005; Sus, 2014, s. 13 passim).

Inną ciekawą koncepcją nawiązującą do idei soft power jest stosunkowo niedawno sformułowana teoria traktująca Unię Europejską jako tzw. market power, którą to nazwę można spolszczyć jako ,mocarstwo gospodarczo-regulacyjne”. Według autora tej teorii, Chada Damro, Unia Europejska oddziałuje na środowisko międzynarodowe w specyficzny sposób, promując nie tylko normy o charakterze ideowo-politycznym, ale także - czy raczej przede wszystkim - poprzez ,uzewnętrznianie”, czyli swoisty eksport jej polityk gospodarczych i społecznych oraz związanych z nimi rozwiązań regulacyjnych funkcjonujących na unijnym Jednolitym Rynku. Taka dyfuzja norm gospodarczo-społecznych istotnie może czynić z Unii swoiste „mocarstwo regulacyjne” na arenie międzynarodowej, biorąc pod uwagę fakt, że niektóre normy unijne (dotyczące np. usług finansowych i telekomunikacyjnych czy ochrony artykułów spożywczych) stały się już standardami stosowanymi na skalę globalną. W ten sposób Unia Europejska niejako bezwiednie, nie poprzez zaplanowane działania, ale dzięki stworzeniu obiektywnie istniejącego, wewnątrzunijnego systemu regulacyjnego oddziałującego na jej relacje gospodarcze z zagranicą może w istotny sposób wpływać na swoje otoczenie międzynarodowe (Damro, 2012, s. 682-699; Bach, Newman, 2007, s. 827 passim).

\section{Argument sily czy siła argumentów?}

Dotychczasowe rozważania wyraźnie wskazuja, jaka może być odpowiedź na pytanie zawarte w tytule niniejszego artykułu - jedną z najważniejszych cech charakteryzujących Unię Europejską jako uczestnika współczesnych stosunków międzynarodowych jest odgrywanie przez nią roli ,łagodnej potegi”, oddziałującej na otoczenie zewnętrzne za pomocą stosowania środków pokojowych, promowania wartości demokratycznych, udzielania wszechstronnej pomocy czy rozwijania współpracy multilateralnej. Oznacza to, że UE zdecydowanie preferuje „siłę argumentów” (gospodarczych, politycznych, dyplomatycznych, kulturowych) pozostających do jej dyspozycji, a nie sięganie po ,argument siły”.

Podkreślić przy tym należy, że takie preferencje nie wynikają - jak utrzymują niektórzy krytycy międzynarodowego zaangażowania Unii - jedynie z faktu, że nie dysponuje ona rozwiniętym arsenałem środków natury hard power (w tym przede wszystkim brakuje jej autonomicznego potencjału militarnego). Nie ulega bowiem wattpliwości, że tego rodzaju pokojowe i demokratyczne aspekty unijnej polityki zagranicznej opierają się na autentycznie przyjętym i głęboko zakodowanym w acquis communautaire oraz 
acquis politique UE systemie norm określanych jako „wartości europejskie”. W ramach katalogu tych norm w odniesieniu do międzynarodowej aktywności Unii na plan pierwszy wysuwają się te, które obejmują - obok promocji szeroko pojmowanych wartości demokratycznych - rozpowszechnianie i stosowanie zasad pokojowego rozwiązywania problemów międzynarodowych. Jednym słowem, wydaje się, że to właśnie ta cecha w największym stopniu czyni z Unii Europejskiej swoistą soft power.

Należy bowiem zdecydowanie podkreślić, że „ogromnym, zapewne najważniejszym dorobkiem wspólnotowych struktur integracji europejskiej jest to, że zdołały one przez cały okres powojenny zapewnić pokojowy rozwój nie tylko swoim coraz liczniejszym członkom, ale także de facto całemu Staremu Kontynentowi” (Milczarek, 2005, s. 15). Rozszerzając ten wątek można dodać, że w całym okresie powojennym europejskie struktury integracyjne przyczyniały się także, pomimo wszelkich słabości swej polityki zewnętrznej, do rozwiązywania szeregu konfliktów w skali regionalnej, a nawet globalnej. Jak określił to syntetycznie Edward Haliżak, Unia Europejska „wnosi wielki wkład w stabilizację i pokojową ewolucję stosunków międzynarodowych w wymiarze regionalnym i globalnym" (Haliżak, 2012, s. 385).

$\mathrm{Na}$ tę niezwykle ważną cechę Unii Europejskiej jako uczestnika stosunków międzynarodowych zwraca uwagę wielu innych badaczy. Stanisław Parzymies przytacza szereg wypowiedzi na ten temat: tak np. zdaniem Christophera Hilla i Michaela Smitha Unia Europejska jest „strefą pokoju w łonie systemu międzynarodowego”, a według Roya Ginsberga: „symbolem, oczywiście niedoskonałym, epickiego pojednania między państwami i pokoju strukturalnego bez precedensu w historii stosunków międzynarodowych". Pojawiają się także opinie, że UE ,jest powszechnie postrzegana jako model pokojowych stosunków międzynarodowych między państwami mającymi za sobą historię krwawych konfliktów" (Parzymies, 2009, s. 22).

To samo dotyczy bycia przez Unię Europejską bardzo ważnym, a może najważniejszym w świecie orędownikiem demokracji, rządów prawa, ochrony praw człowieka itp., do czego dochodzi jeszcze bardziej wymierna rola największego dostarczyciela pomocy rozwojowej (Zajączkowski, 2013). Co więcej, odgrywanie tego typu ról stanowi unikatową cechę, wyraźnie odróżniającą UE od praktycznie wszystkich innych aktorów na scenie globalnej. Takiej pozytywnej oceny nie może nawet zmieniać fakt, że stopień szczerości przyjmowania przez instytucje unijne czy poszczególne państwa członkowskie „wartości europejskich”, a zwłaszcza sposoby wprowadzania ich w życie wywołują liczne, często jak najbardziej uzasadnione zarzuty i kontrowersje. Niemniej nie można zanegować empirycznie udowodnionego faktu, że pomimo wszelkich wątpliwości w tym zakresie międzynarodowa działalność Unii Europejskiej opiera się w teorii i w praktyce na tych wartościach - chociaż osąd ich realnej skuteczności podlega rzecz jasna rozmaitym ocenom.

Wskazać jednocześnie trzeba, że odgrywanie przez UE roli soft power - czy to w wymiarze "mocarstwa niewojskowego", czy też „mocarstwa normatywnego" - nie odbywa się jednak w sposób bezproblemowy. Dla przedstawienia pełni obrazu trzeba bowiem uwzględnić występowanie konfliktów pomiędzy poszczególnymi rolami odgrywanymi przez Unię Europejską. Konflikty takie pojawiają się w rozmaitych konfiguracjach pomiędzy samymi instytucjami wspólnotowymi, instytucjami a państwami członkowskimi, poszczególnymi państwami itd. Napięcia mogą również pojawiać się 
podczas jednoczesnej realizacji kilku ról, np. mediatora w konfliktach międzynarodowych oraz dostawcy pomocy, kiedy osiąganie naraz wszystkich pożądanych celów okazuje się trudne czy wręcz niemożliwe.

Tego rodzaju brak spójności w ramach międzynarodowej aktywności Unii Europejskiej wynika z całej gamy przyczyn, wśród których jedno z czołowych miejsc zajmuje sygnalizowany już problem braku jasno zarysowanego finalité politique europejskich procesów integracyjnych ( $W$ poszukiwaniu, 2015). Problem ten, będący przedmiotem ożywionych polemik polityczno-ideologicznych oraz badawczych, zdaje się narastać w obliczu kolejnych odsłon wyraźnego kryzysu, jaki przeżywa obecnie UE. Zjawiska i procesy kryzysowe maja przy tym nie tylko najbardziej odczuwalny i widoczny charakter gospodarczo-społeczny czy polityczny, ale również - a może przede wszystkim - aksjologiczny (Czachór, 2015, s. 7-8).

Jak słusznie wskazuje Zbigniew Czachór, „nadal niezbędnie konieczne jest precyzyjne zdefiniowanie wizji Unii, także w kontekście przyszłości integracji”, przy czym muszą być zachowane podstawowe zasady stanowiące podstawy normatywne całego projektu integracyjnego. Autor ten zalicza do nich dialog, kompromis, niedyskryminację, solidarność i spójność europejską (a więc normy z katalogu „wartości europejskich”), a państwa członkowskie UE ,zobowiązane są ciaggle udowadniać swą zdolność do wypełniania zobowiązań integracyjnych, które na siebie przyjęły". Jednocześnie ,nie może być tu miejsca na pogłębiający się eurorealizm czy też eurosceptycyzm”, tym bardziej, że ,interesy narodowe państw członkowskich są do pogodzenia z interesem wspólnym Unii Europejskiej” (Czachór, 2015, s. 13).

Pomimo zauważalnych przejawów wielopłaszczyznowego kryzysu, Unia Europejska nadal pozostaje znacząca soft power, mającą możliwości wpływania na państwa ościenne czy całe regiony tak, aby zachodziły w nich pożądane przez nią zjawiska oraz procesy pokojowe i demokratyczne (The European Union, 2010, s. 1-13). Nie odbywa się to wprawdzie w sposób bezproblemowy; jak również tempo czy zakres skuteczności tego oddziaływania może budzić wątpliwości. Co więcej, nie wolno przy tych ocenach wpadać w pułapkę nadmiernego „idealizmu teoretyzującego”. Należy bowiem pamiętać, że traktowanie Unii Europejskiej wyłącznie jako „łagodnej potęgi” grozi nie tylko wypaczeniem jej rzeczywistego obrazu, ale także odebraniem jej ważnych atrybutów w innych dziedzinach.

Przewaga elementów soft power w międzynarodowych działaniach Unii nie czyni z niej bynajmniej „,mocarstwa jednowymiarowego”. Jak wykazuje praktyka polityczna oraz oceny analityków i badaczy, w razie potrzeby czy konieczności WE/UE potrafiły i potrafią jednak stosować także argumenty i środki z zakresu hard power, łącznie z użyciem siły militarnej (Hill, 2010, s. 184-185). Na taką ewentualność mają również przygotować Unię wspomniane postanowienia Europejskiej Strategii Bezpieczeństwa. Jak określił to wprost na forum Parlamentu Europejskiego ówczesny sekretarz generalny NATO Anders F. Rasmussen: „Unia Europejska musi zrozumieć, że sama «miękka siła» to w rzeczywistości brak jakiejkolwiek siły” (cyt. za Piskorska, 2014, s. 29).

Generalnie rzecz biorąc można stwierdzić, że koncepcja soft power, wraz z powiązanymi z nią teoriami civilian power czy normative power, nie powinny być traktowane jedynie jako użyteczne narzędzia badawcze - które zresztą mogą zawodzić przy badaniach nad bytem tak skomplikowanym oraz nieokreślonym jak Unia Europejska 
i prowadzić do tego, co Zbigniew Czachór nazywa "dryfowaniem konceptualnym” badaczy zajmujących się europeistyką (Czachór, 2015, s. 13). Niemniej koncepcje te można czy wręcz należy traktować także jako swoiste wytyczne o charakterze zarówno ideowym, jak i pragmatycznym, pozwalające formułować diagnozy i zalecenia dotyczące współczesnych oraz przyszłych procesów integracji europejskiej.

\section{Bibliografa}

Allen D., Smith M. (1998), The European Union's Security Presence: Barrier, Facilitator, or Manager?, w: The European Union in the World Community, red. C. Rhodes, CO: Lynne Rienner, Boulder.

Antczak A. (2012), Role międzynarodowe Unii Europejskiej. Aspekty teoretyczne, Vizja Press\&IT, Warszawa.

Bach D., Newman A. L. (2007), The European regulatory state and global public policy: micro-institutions, macro-influence, ,Journal of European Public Policy” no. 6.

Barburska O. (2013), European Integration in Motion: 60 Years of Successes and Failures, w: Introduction to European Studies: A New Approach to Uniting Europe, red. D. Milczarek, A. Adamczyk, K. Zajączkowski, Centre for Europe, University of Warsaw, Warsaw.

Barburska O. (2016), Polityka zagraniczna Unii Europejskiej: aspekty teoretyczne i metodologiczne, „Studia Europejskie”, nr 3.

Bendiek A., Kramer H. (2010), The EU as a Strategic International Actor: Substantial and Analytical Ambiguities, ,European Foreign Affairs”, no. 15.

von Bogdandy A. (2000), The European Union as a Human Rights Organization? Human Rights and the Core of the European Union, „Common Market Law Review” vol. 37.

Bull H. (1982), Civilian Power Europe: A Contradiction in Terms?, „Journal of Common Market Studies", vol. 21, no. 2.

Cooper R. (2004), The Breaking of Nations: Order and Chaos in the $21^{\text {st }}$ Century, Atlantic Books, London.

Czachór Z. (2015), Kryzys w Unii Europejskiej. Propozycje nowych pól i pytań badawczych, „Rocznik Integracji Europejskiej", nr 9.

Czaputowicz J. (2013), Teoretyczne wyjaśnienia Europejskiej Polityki Bezpieczeństwa i Obrony, „Stosunki Międzynarodowe”, nr 2.

Damro Ch. (2012), Market power Europe, ,Journal of European Public Policy”, no. 5.

Duchêne F. (1972), Europe's Role in World Peace, w: Europe Tomorrow: Sixteen Europeans Look Ahead, red. R. Mayne, Fontana, London.

Duchêne F. (1973), The European Community and the Uncertainties of Interdependence, w: A Nation Writ Large? Foreign Policy Problems before the European Community, red. M. Kohnstamm, W. Hager, Macmillan, London.

European Union. External Action, http://eeas.europa.eu/csdp/missions-and-operations/index_en.htm, 15.04.2016.

Forsberg T. (2011), Normative Power Europe, Once Again: A Conceptual Analysis of an Ideal Type, „Journal of Common Market Studies”, no. 49.

Galtung J. (1973), The European Community. A Superpower in the Making, Harper Collins Publishers Ltd, London.

Gerrits A. (2009), Normative Power Europe: Introductory Observations on a Controversial Notion, w: Normative Power Europe in Changing World: A Discussion, red. A. Gerrits, Netherlands Institute of International Relations, Clingendael, December. 
Grosse T. G. (2009), O słabościach polityki zagranicznej Unii Europejskiej, „Analizy Natolińskie”, nr 8 .

Haliżak E. (2002), Wspótzależność integracji ekonomicznej i politycznej w Unii Europejskiej-przyczynek do rozważań o istocie ekonomii politycznej stosunków międzynarodowych, w: Unia Europejska nowy typ wspólnoty międzynarodowej, red. E. Haliżak, S. Parzymies, Oficyna Wydawnicza ASPRA-JR, Warszawa.

Hill Ch. (2010), Cheques and balances. The European Union's Soft Power strategy, w: Soft Policy and US Foreign Policy. Theoretical, historical and contemporary perspectives, red. I. Parmar, M. Cox, Routledge, New York.

Hill Ch. (1990), European foreign policy, power bloc, civilian model, or flop?, w: The Evolution of an International Actor. Western Europe's New Assertiveness, red. R. Rummel, Westview Press, Boulder.

Hyde-Price A. (2008), A 'Tragic Actor'? A Realist Perspective on 'Ethical Power Europe', „International Affairs", no. 1.

Kagan R. (2003), Of Paradise and Power. America and Europe in the New World Order, Alfred A. Knopf, New York.

Laïdi Z. (2008), Norms Over Force: The Enigma of European Power, Palgrave Macmillan, New York.

Leonard M. (2005), Will Europe Run the 21st Century?, Fourth Estate, London-New York.

Lodge J. (1993), From Civilian Power to Speaking with a Common Voice: The Transition to CFSP, w: The European Community and the Challenge of the Future, red. J. Lodge, $2^{\text {nd }}$ edition, Pinter, London.

Malinowski K. (2012), Analiza polityki zagranicznej i teoria ról. Możliwości zastosowania do badań nas zaangażowaniem międzynarodowym Unii Europejskiej, w: Teorie w studiach europejskich. W kierunku nowej agendy badawczej, red. J. Ruszkowski, L. Wojnicz, Instytut Politologii i Europeistyki Uniwersytetu Szczecińskiego, Szczecin-Warszawa.

Manners I. (2009), The EU's Normative Power in Changing World Politics, w: Normative Power Europe in Changing World: A Discussion, red. A. Gerrits, Netherlands Institute of International Relations, Clingendael, December.

Manners I. (2002), Normative Power Europe: A Contradiction in Terms?, „Journal of Common Market Studies", no. 2.

Maull H. (1990), Germany and Japan: The New Civilian Powers, „Foreign Affiars”, no. 5.

Maull H. (2000), Germany and the Use of Force. Still a 'Civilian Power'?, „Survival”, no. 2.

Milczarek D. (2003), Pozycja i rola Unii Europejskiej w stosunkach międzynarodowych. Wybrane aspekty teoretyczne, Centrum Europejskie Uniwersytetu Warszawskiego, Warszawa.

Milczarek D. (2005), Unia Europejska we wspótczesnym świecie, Centrum Europejskie Uniwersytetu Warszawskiego, Warszawa.

Nowa globalna strategia UE, Euractiv, http://www.euractiv.pl/polityka-zagraniczna/artykul/nowaglobalna-strategia-ue-008634, 28.06.2016.

Nye J. S. (2007), Soft power. Jak osiagnać sukces w polityce światowej, Wydawnictwa Akademickie i Profesjonalne, Warszawa.

Nye J. S. (2011), Przyszłość sity, Wydawnictwo Naukowe PWN, Warszawa.

Parzymies S. (2009), Unia Europejska jako uczestnik stosunków międzynarodowych, w: Dyplomacja czy siła? Unia Europejska w stosunkach międzynarodowych, red. S. Parzymies, Wydawnictwo Naukowe Scholar, Warszawa.

Pietraś J. Z. (1989), Pojęcie i klasyfikacja ról międzynarodowych, UMCS, Lublin.

Piskorska B. (2014), Wpływ procesów antydemokratycznych w państwach Partnerstwa Wschodniego na Europejska Politykę Sasiedztwa, „Zeszyty Natolińskie”, nr 59. 
Sjursen H. (2006), The EU as a normative power: how can this be?, „Journal of European Public Policy", no. 2.

Skolimowska A. (2015a), Normatywna potęa Unii Europejskiej: struktura teoretyczno-metodologiczna badania, w: Normatywna potęga Unii Europejskiej w obliczu umiędzynarodowionych konfliktów wewnętrznych, red. A. Skolimowska, Instytut Politologii UKSW, Warszawa.

Skolimowska A. (2015b), Potęa norm w stosunkach międzynarodowych, w: Normatywna potęa Unii Europejskiej w obliczu umiędzynarodowionych konfliktów wewnętrznych, red. A. Skolimowska, Instytut Politologii UKSW, Warszawa.

Smith K. E. (1997), Paradoxes of European Foreign Policy. The Instruments of European Union Foreign Policy, EUI Working Papers no. 97/68, San Domenico.

Smith K. E. (2000), The End of Civilian Power Europe. A Welcome Demise or Cause for Concern?, „The International Spectator”, no. 2.

Smith K. (2001), The EU, Human Rights and Relations with Third Countries: 'Foreign Policy'with an Ethical Dimension, w: Ethics and Foreign Policy, red. K. Smith, M. Light, Cambridge University Press, Cambridge.

Stavridis S. (2001), Why the 'Militarising' of the European Union is Strengthening the Concept of a Civilian Power Europe, EUI Working Papers 2001, no. 17, San Domenico.

Stavridis, S. (2002), 'Militarising' the EU: the Concept of Civilian Power Europe Revisited, „The International Spectator", no. 4.

Sus M. (2014), Unia Europejska jako siła transformacyjna na Wschodzie w latach 2009-2013. Przypadek Ukrainy, „Zeszyty Natolińskie”, nr 56.

The European Union and Democracy Promotion. A Critical Global Assessment (2010), red. R. Young, Johns Hopkins University Press, Baltimore.

Traktat z Lizbony. Traktat o Unii Europejskiej. Traktat o funkcjonowaniu Unii Europejskiej (2010), Instytut Wydawniczy EuroPrawo, Warszawa.

Whitman R. (1998), From Civilian Power to Superpower? The International Identity of the European Union, Macmillan, Basingstoke-London.

W poszukiwaniu finalité politique Unii Europejskiej. Aspekty teoretyczne i praktyczne (2015), red. L. Wojnicz, D. Rdzanek, M. Potkańska, Instytut Politologii i Europeistyki Uniwersytetu Szczecińskiego, Instytut Europeistyki Uniwersytetu Warszawskiego, Szczecin-Warszawa.

Zielonka J. (1998), Explaining Euro-Paralysis. Why Europe is Unable to Act in International Politics, Macmillan, Basingstoke.

Zajączkowski K. (2013), European Union's Development Assistance - Framework, Priorities and Directions, w: Introduction to European Studies. A New Approach to Uniting Europe, red. D. Milczarek, A. Adamczyk, K. Zajączkowski, Warsaw.

Zajączkowski K. (2014), O brakach i niedostatkach w polityce zagranicznej UE, „Studia Europejskie", nr 3.

Zięba R. (2011), Polityka zagraniczna Unii Europejskiej, w: Polityka zagraniczna. Aktorzy -potencjaty - strategie, red. T. Łoś-Nowak, Wydawnictwo Poltext, Warszawa.

\section{Streszczenie}

W artykule podjęto próbę analizy tego, w jaki sposób Unia Europejska odgrywa charakterystyczną dla siebie międzynarodową rolę tzw. „łagodnej potęgi” (soft power). W rozważaniach wzięto pod uwagę fakt, że UE oddziałuje na swoje otoczenie zewnętrzne za pomocą przede wszystkim środków o charakterze politycznym, dyplomatycznym, ekonomicznym, kulturowym itp., a nie poprzez zastosowanie „twardych” (hard) instrumentów przymusu (w tym siły zbrojnej). Koncepcja Unii Europejskiej jako soft power posłużyła jako punkt wyjścia do prezentacji 
innych teorii bezpośrednio z nią związanych, w pierwszym rzędzie koncepcji UE jako civilian power, a następnie normative power i innych teorii pochodnych. Uwzględniają one rozmaite aspekty specyfiki Unii Europejskiej jako unikatowego uczestnika współczesnych stosunków międzynarodowych, powstrzymującego się od wykorzystywania siły militarnej i promującego wartości demokratyczne.

Slowa kluczowe: Unia Europejska, soft power, civilian power, normative power, polityka zagraniczna UE

\section{The argument of power, or power of arguments? The European Union in international relations as a 'soft power'}

\section{Summary}

The article attempts to analyze how the European Union plays its distinctive international role as a so-called soft power. The paper takes into account the fact that the EU acts on its external environment using primarily of a political, diplomatic, economic and cultural means, and not through the use of 'hard' instruments of coercion (including the armed forces). The concept of the European Union as a 'soft power' serves as a starting point for the presentation of other theories directly related to it - in the first place the concept of the EU as a 'civilian power' and 'normative power' and other theories derivatives. They take into account various aspects of the specificity of the European Union as a unique participant in contemporary international relations, restraining from using military force and promoting democratic values.

Key words: European Union, soft power, civilian power, normative power, foreign policy of the EU 
